\title{
A REVIEW OF THE FEDERAL VALUATION OF RAILROADS
}

\author{
T. P. ARtaud
}

In view of the extensive discussion of the various phases of the railroad situation, and the many angles from which it has been approached by current writers, it is somewhat surprising to note what little consideration has been given by the public to the valuation work that is being prosecuted by the Interstate Commerce Commission as a factor in regulatory functions. For many years prior to the passage in I9I3 of Section I9-a of the act to regulate commerce, ${ }^{1}$ authorizing and requiring the work, the Interstate Commerce Commission had repeatedly urged upon Congress the necessity for such an investigation and appraisal to enable the Commission properly to perform its duties.2 Economists

\footnotetext{
${ }^{1}$ Act of March I, I913 (37 Stat. at L. 70I).

${ }^{2}$ The first recommendation of the Interstate Commerce Commission relative to the subject of valuation of railways is contained on pages $26-3 \mathrm{I}$, inclusive, of its Seventeenth Annual Report in 1903. The following quoted excerpts have been taken from that report:

"Among the subjects which deserve the attention of the Congress is the need of a trustworthy valuation of railway property. As such a valuation, on the theory and by the methods about to be suggested, would require the aid of suitable legislation, it may be appropriate to discuss the matter briefly in the present report.

"There are two leading reasons why an authoritative valuation of railroad property is of increasing importance. In the first place, the judicial rules for the determination of reasonable rates for freight and passenger traffic, so far as those rules have been laid down in the decisions of the courts, include and lay stress upon the fair value of the roads whose rates are the subject of complaint. It is sufficient for the present purpose to state that no tribunal upon which the duty may be imposed, whether legislative, administrative, or judicial, can pass a satisfactory judgment upon the reasonableness of railway rates without takitng into consideration the value of railway property. This is so, not only because of the nature of the question involved, but especially for the reason that the courts. have held in numerous cases that an enforced rate so low as to deprive the carrier of its property, that is, broadly speaking, the right to a reasonable return therefrom, is repugnant to the Constitution."
}

The Commission has reference here, of course, to the Fifth and Fourteenth Amendments to the Constitution which prohibit the taking of private property for public use without just compensation and without due process of law. If the rates prescribed by a regulatory body do not yield sufficient revenue. to meet operating expenses, it is evident that continued operation under such rates will diminish the assets of the carrier and thus constitute a deprivation of its property. Property can no more be confiscated piece-meal by such a process than it can be seized in toto.

Proceeding with its discussion, the Commission states further:

"Another reason for such valuation is scarcely less important. Closely connected with the question of reasonable railway rates stands the question of reasonable railway taxation. The general fact relative to railway taxation in this country is that the value of corporate property, real and personal, is made the basis of public 
and state railroad and public service commissions ${ }^{3}$ alike joined in its recommendations and the courts manifested an increasing tendency toward regarding the value of public service property as one of the controlling factors in all regulatory proceedings. ${ }^{4}$ The years inter-

contributions. Some few States tax railways on the basis of earnings, but there is no tendency for this practice to become general.

"It would be wholly outside the purpose of this report to consider the general question of railway taxation. That stbject lies within the jurisdiction of the States. When, however, it is recognized that railway taxes amount to between 4 and 5 per cent. of the aggregate of operating expenses, and that on this account a reasonable charge upon-interstate traffic may be affected by the manner in which the States administer their taxing laws, it may well be claimed that the valuation of railway properties becomes a matter of Federal concern."

See also Nineteenth to Twenty-sixth Annual Reports of the Interstate Commerce Commission, rgo5-rgr2, which contain the recommendations and discussions of the Commission upon this subject.

${ }^{3}$ In the hearings before the Senate Committee on Interstate Commerce on February II, I9I3, Professor E. W. Bemis, utility expert, formerly of the University of Chicago, in discussing the Valuation Act, said at page 54:

"The general plan and purpose of the bill appears to be altogether sound as it is written. The valuation of all the elements of a road is essential to a proper study of the road question. Some of these elements are more important than others. Some will be thought more important at one time and others at another time. While some matters seem of little importance to some, and others of greater importance, I see nothing here that is not recognized in the courts as a matter to be considered. I understand that the purpose of this bill is to gather together in as scientific a manner as possible this information, and that appears altogether wise."

In the same hearings on February 14, I9I3, Professor John R. Commons, of the University of Wisconsin, member of the Industrial Commission of Wisconsin, said at page I03:

"But there ought to be somebody there who knows the literature and the theories of value, so that he can properly weigh the different theories and properly distinguish between them, and also between this reasonable value, which economists do not usually take into account, and these market values which are the dominant ideas in the minds of economists.

"As to the organization of such a commission as has been proposed, it appears to me that unquestionably the organization should be under the control of and the appointment of the valuers should be made by the Interstate Commerce Commission."

In this connection; see also Report of the Committee on Railroad Taxes and Plans for Ascertaining Fair Valuation of Railroad Property-National Association of Railway Commissioners.-Proceedings of the Twenty-fourth Annual Convention, held at Washington, D.' C., November 19, I912, pp. 34-90, which gives the status of railway valuation performed by the various state commissions in Igra. Reports of the same committee on valuation, and specific recommendations, will be found in the proceedings of the Annual Convention of the National Railway Commissioners for preceding and succeeding years.

4 The only way by which the protection of the Fifth and Fourteenth Amendments against inadequate rates can be invoked is by showing the value of the properties affected by such rates, and the courts have accordingly been concerned with the value of the property of a public utility in' a consideration of the reasonableness of the rates charged. The reason appears in repeated statements of the Supreme Court of the United States, as for instance, in the case of Smyth $v$. Ames (1898) I69 U. S. 466,549 , I8 Sup. Ct. 4 I 8,434 , where the court said, "what the company is entitled to ask is a fair return upon the value of that which it employs 
vening since the passage of the valuation act have been kaleidoscopic in railroad affairs; changes have taken place which in I9I3 would have been deemed impossible, but nothing has occurred to modify the necessity for a complete valuation of common-carrier property; on the contrary, all of the radical changes, both actual and proposed, have laid added emphasis upon the data required by Section I9-a. Congress had builded better than it knew. The Transportation Act of $1920^{5}$ is absolutely dependent in its major provisions upon the value of the property affected, and itself states that this value shall be that found under Section I9-a.

It is the purpose of this article to sketch briefly the conditions which led to the inception of federal valuation, the nature and scope of its findings, and its uses, both actual and potential.

The Valuation Act was passed as the result of demands from a number of different sources. In the first place, railroads and other public service corporations had, in a number of instances, presented appraisals made by themselves to the courts in litigation resulting from the regulation of rates by various state commissions having regulatory powers. This line of testimony was designed to show that the rates complained of were confiscatory and therefore unconstitutional. Because of the soundness and plausibility of the fundamental idea involved, the courts, including the Supreme Court of the United States, showed an increasing disposition to hold that an appraisal which had been properly made was an important consideration in fixing the limit below which rates could not be reduced. ${ }^{6}$ This attitude of the courts in turn stimulated the

for the public convenience," (italics ours) and in the Mimesota Rate Cases (I9r3) 230 U. S. $352,434,33$ Sup. Ct. 729, 754 where the Supreme Court held that a railroad property "rests secure under the constitutional protection which extends not merely to the title but to the right to receive just compensation for the service given to the public." Again, in the case of San Diego Land \& Tozm Co. $v$. Jasper (1902) I89 U. S. 439, 442, 23 Sup. Ct. 57I, 572, in which the court, speaking through Mr. Justice Holmes, said: "It no longer is open to dispute that under the Constitution "what the company is entitled to demand is a fair return upon the reasonable value of the property at the time it is being used for the public.'"

Further cases in support of this doctrine are: San Diego Land \& Toun Co. v. National City (I899) I74 U. S. 739, x9 Sup. Ct. 804; Cotting v. Kansas City Stockyards Company (I90I) I83 U. S. 79, 22 Sup. Ct. 30; Willcox v. Consolidated Gas Co. (1909) 212 U. S. 19, 29 Sup. Ct. 192; Knoxville v. Water Company (1909) 212 U. S. I, 29 Sup. Ct. I48; Kansas City So. Ry. v. U. S. (I9r3); 231 U. S. 423, 34 Sup. Ct. I25; Reagan v. Earmers' Loan \& Trust Co. (1894) I54 U. S. 362, I4 Sup. Ct. I047; Omaha v. Omaha Water Co. (I910) 218 U. S. I80, 30 Sup. Ct. 615; Covington and Lexington Turnpike v. Sandford (1896) I64 U. S. 578, i7 Sup. Ct. I98; Railroad Commission Cases (1896) II6 U. S. 307, 26 Sup. Ct. 334. The Supreme Court in the case of Cedar Rapids Gaslight Co. v. Cedar Rapids (I912) 223 U. S. $655,667,32$ Sup. Ct. 389 , 390, limits the rate-making power of a state by the following language: "The general power reserved to regulate rates was limited only by the Fourteenth Amendment."

${ }^{5}$ Act of February 28, I920' (4I Stat. at L. 456).

- See supra note 4. It is of considerable interest in this connection that the Supreme Court of the United States has said that "good will and earning power 
desire, already present because of other considerations, of regulatory bodies to have data within their own possession with which to pass upon, and rebut if necessary, the carrier's claims. As early as 1907 fifteen states had provided for more or less complete valuations of railroad property. Such valuations, however, had been only partially the outgrowth of rate regulation. The majority of them were appraisals for the purposes of taxation and one (Texas) was for the purpose of regulating security issues. Furthermore, although not applied to railroads, the concept of valuation had become very definitely fixed in the minds of both courts and commissions through the public acquisition of such properties as gas, water, and electric plants. The four, that is, rate regulation, taxation, control of security issues, and acquisition, represented the purposes' of appraisals made and authorized up to the passage of the federal Valuation Act. It was then clearly understood that, since monopolistic or semi-monopolistic corporations were removed from the control of natural laws of competition, supply and demand, man-made, artificial or political laws of regulation must be invoked, and these must rest upon a definite, tangible, and essential basis.

In I903 the annual report of the Interstate Commerce Commission to Congress contained a specific recommendation for federal valuation, giving reasons therefor and the possible methods to be pursued. The reasons advanced were two-fold: first, the judicial rules for determining reasonable and lawful rates stressed the "fair value" of the property devoted to the public convenience; and second, the taxation of railroad property within the several states failed to show the uniformity which might reasonably be expected from the general uniformity of methods of taxation. 'Reduced to a mileage basis, the taxes varied from $\$ 9$ per mile in the Indian Territory to $\$ I, 4$ Or per mile in Massachusetts. The significance of this disparity is manifest when it is remembered that railway taxes amounted to between four and five per cent. of the aggregate operating expenses. The possible methods to be pursued were enumerated as follows: (I) acceptance of the book items representing cost of road and equipment; (2) a determination of the market value of securities issued; (3) a complete inventory of both physical and non-physical values.

due to effective organization, like past losses, should be considered in determining whether a rate charged by a public utility is reasonable," but has held that in determining whether a rate is "confiscatory" they should be "excluded from the base value." See Galveston Electric Company v. City of Galveston (1922) 42 Sup. Ct. 35i, 355. Of equal importance was the case of Ben Avon Borongh v. Ohio Valley Water Co. (I920) 253 U. S. 287,40 Sup. Ct. 527, which held that the findings of fact of a state regulatory body as to the value of the property of a public utility were subject to judicial review. In this case the Supreme Court said:

"In all such cases, if the owner claims confiscation of his property will result, the State must provide a fair opportunity for submitting that issue to a judicial tribunal for determination upon its own independent judgment as to both laze and facts; otherwise the order is void because in conflict with the due process clause." 49 Sup. Ct. 528 . (Italics ours.) 
With respect to the first of these three methods, the Commission stated that no one familiar with the practice of railway accounting could maintain that the book cost was an indication of the present value of the property both because the amounts entered as costs did not, except perhaps, in rare instances, represent the capital originally put into the enterprise, and because even in these few instances, the fluctuations in prices of material and labor would render the cost useless as a measure of present value. In other words, the railroad balance sheet was of no significance for the purposes of valuation. To these statements should be added that book costs do not purport to include non-physical values and that under the then existing accounting methods there was utter lack of uniformity among carriers in providing for additions and retirements in capital accounts.

Concerning valuation on the basis of the market value of the stocks and bonds, which up to that time seemed to have received the qualified approval of the courts, the Commission pointed out that sales of securities for permanent investment were few as compared with those to syndicates for consolidation and control. It is apparent that the latter form no correct measure of the value of the properties they represent. Further, the great majority of the securities were not bought and sold upon the market so that insufficient transactions were of record to serve the purpose. In response to a Senate resolution, ${ }^{7}$ the Commission had two years prior to this time attempted to make such an appraisal, and had then reported that of the two thousand and more corporations dealt with, less than two hundred twenty-five were reported in such a manner as to permit a satisfactory computation of value to be made on that basis.

The Commission therefore recommended that an appraisal by the third method, namely, a complete inventory of both physical and nonphysical values, be authorized by Congress.

Two years later, in I905, the Interstate Commerce 'Commission, in coöperation with the Bureau of the Census, made a "commercial valua-

T The following is quioted on p. 3I of the Seventeenth Annual Report of the I. C. C. (I903), made in response to the resolution:

" 'It may not be inappropriate, as bearing upon the extent to which reliance can be placed upon the figures submitted, to state the difficulties encountered in this computation. The chief difficulty was found in the fact that by far the larger proportion of railway securities are not subject to extensive purchase and sale, and on this account fail to disclose the market price. This report deals with over two thousand corporations, while the number whose securities were quoted on the stock market in such a manner as to enable a satisfactory computation of the value of the property which they represent, in conformity with the rule embodied in the resolution, did not exceed two hundred and twenty-five." "

The Commission stated its conclusions on p. 3 I of its Seventeenth Annual Report:

"While market valuations of such securities as show a wide market may be of great use in checking values arrived at by other methods, or in enabling a correct interpretation of commercial conditions, if an authoritative and trustworthy valuation of railway properties is to be arrived at, the balance sheet, whether on the side of assets or liabilities, cannot be accepted as the starting point for investigations." 
tion" of railroad property. ${ }^{8}$ The two considerations upon which this was based were, first, the expectation of income arising from the use of railroad property, and second, the strategic significance of the road. The material made use of was (a) the operating and financial accounts of carriers, (b) inter-railway contracts and agreements, and (c) the records of the stock market. The sole purpose of this valuation was for the census as one step in determining the wealth of the nation, and the Commission carefully. pointed out that the estimate could not, from its very nature, be used for the more important purposes of valuation. It could not be employed for rate regulation, since the values found were the result of income derived under an established schedule of rates, and under'a different schedule the values would be different. It could not serve as a basis for discussion of government acquisition, since the values regarded as a private enterprise might, and probably would, require modification from considerations of public utility. It would not afford a general basis for taxation, since the laws of a majority of the states confine taxation of railroad property to the physical elements, and only a few provide for levy on the basis of "commercial value." It would not provide a proper basis for regulating security issues, since these were themselves essential elements from which value was determined.

Each subsequent annual report until the adoption of the Valuation Act, renewed the recommendation for an appraisal of "physical and non-physical values," not subject to these disabilities, and additional arguments were advanced in its favor. The Commission had recently brought about the introduction of depreciation accounts into the standard railway accounting practice for the purposes, as stated by it, of (a) protecting "the investor against the depletion of his property by understatement of the cost of maintenance" and (b) protecting "the public against unduly high rates by charging improvements to the cost of transportation." It urged that the proper administration of these important accounts required complete and accurate information concerning the value of the property to which they applied, and that such data could be secured only by a formal appraisal embracing all classes of railway property. A standard form of balance sheet was also prescribed, the purpose of which was to parallel the statements of assets and liabilities, thus disclosing the financial standing of the reporting carrier. Since, however, the statements on the asset side were subject to the uncertainties and inaccuracies previously discussed, the Commission was, without the physical valuation advocated, utterly unable to test the adequacy of the figures reported. Congress had authorized and required a uniform system of accounts, but this provision was impotent without further steps to secure soundness in the reports made thereunder.

\footnotetext{
${ }^{8}$ See (I905) Nineteenth Annual Report of Interstate Commerce Commission, pp. 88-92, inclusive.
} 
. In I909 point was given to the Commission's arguments in favor of an appraisal by suits brought by certain western roads to enjoin rates on lumber from the Pacific Coast to the East.9 These same roads had two years previously introduced before the courts in the Spokane case ${ }^{10}$ an appraisal made by their own forces, and now presented another, made on the same basis, which exceeded the former by twenty-five per cent. The Commission was absolutely powerless to meet this testimony or to defend the rates against the attack of the carriers.

The advocacy of the federal Commission was generally supported by the states, many of which had begun or provided for appraisals of the property within their respective borders. Such appraisals were necessarily limited. Usually the funds available were inadequate; the authority of the state commissions extended to intrastate matters only and it was at least doubtful whether they could compel returns to orders on carriers or gain access to records covering matters without their territorial limits; the appraisals already made showed the widest discrepancies both in scope and in results among the several states and there seemed to be no possibility of obtaining uniformity except through an inquiry national in extent and made under the authority of the Federal Government. The National Association of Railway Commissioners had maintained a standing committee on the "Valuation of Railway Property" for more than a decade; its reports for several years prior to the adoption of the Valuation Act embraced recommendations for a federal appraisal.11

As a result of this insistence on the part of the federal and state commissions, coupled with court decisions unmistakably showing the importance of valuation in judicial review of rate regulation, ${ }^{12}$ bills providing for a complete appraisal by the Interstate Commerce Commission were repeatedly brought before Congress. Senator LaFollette presented three between the years 1906 and I909 and others were offered in the Senate from time to time. House bills were presented in IgO7 and each year thereafter until the passage in I9I 3 of H. R. 2I544, introduced by Representative Adamson. The subject was advocated by President Roosevelt in I908, was favorably discussed by President Taft

\footnotetext{
- See (I909) Twenty-third Annual Report of Interstate Commerce Commission, p. 6.

Reference was also made to the fluctuating appraisal in the Spokane case by Mr. Halbert P. Gillette, of New York, in his address before the Igth Annual Convention of National Association of Railway Commissioners. (I907) Proceedings of the rgth Ann. Conv., N. A. R. C., 47.

${ }^{10}$ The importance of the question whether a railway shall be allowed to earn a return upon the unearned increment represented in the value of its right of way is illustrated by the facts in the case of City of Spokane $v$. Northern Pacific Ry.

(1909) I5 I. C. C. Reports, 376, 392, but is not discussed or decided. .

"See supra note 3.

${ }^{2}$ Sinyth v. Ames, supra note 4; Mimesota Rate Cases, supra note 4; Kansas City So. Ry. v. U. S., supra note 4 .
} 
in his speech of acceptance in 1908 and in his message of I9II. The Democratic and Progressive platforms of I9I2 advocated the passage of such legislation, hence it was a popular and nonpartisan measure. The work has been prosecuted under both Democratic and Republican administrations since the passage of the act in I9I3.

Such were the considerations and the history under which the work was launched. The nature and the scope of it will be briefly summarized from a non-technical standpoint.

The Bureat of Valuation was organized by the Interstate Commerce Commission in I9I 3 with the late C. A. Prouty, who resigned from the Commission for that purpose, as Director. Owing to the necessity of building up an efficient technical force through Civil Service and the consequent lapse while examinations were announced, applicants rated, and appointments made, the work did not get under way until well into the following year. From that time, the Bureau of Valuation expanded steadily until I9I7 when it reached its maximum personnel of approximately $I, 600$ people, with district offices at Washington, Chattanooga, Chicago, Kansas City, and San Francisco. There are approximately 250,000 miles of interstate steam railroads in the United States, and this territory was divided among the five district offices, each being assigned approximately 50,000 miles of road. The field work was substantially completed in the latter part of I92I, and during that year the district offices were abandoned and the remaining office work was concentrated in Washington. As of April, I922, the force was reduced to approximately 600 employees.

The organization followed the natural subdivision of the work undertaken, being divided into the engineering, the land, and the accounting sections. The engineering section deals with the estimated cost of reproduction new and cost of reproduction less depreciation of physical property other than land. This includes all items of the road itself (grading, track, bridges, station, office and roadway buildings, shops, power plants, tools, machinery, elevators, docks, telephone and telegraph lines, etc.); equipment (locomotives, cars, motors, work trains, and other rolling stock); and general expenditures (organization and legai expense, taxes and interest during theoretical reconstruction, etc.). Its function is to present the estimated costs of reproduction of the several elements of the road new, and also to apply to these figures condition per cents which will produce the value of the service life remaining in the units of physical property in place. ${ }^{13}$

The land section, following the ruling of the Supreme Court in the Minnesota Rate Cases, ${ }^{14}$ decided shortly after the passage of the Val-

\footnotetext{
${ }^{13}$ See Valuation Docket No. 2, Interstate Commerce Commission, Texas Midland Railroad, Appendix 3, page I08, for statement of methods employed in the valuation of railway property.

${ }_{14}$ The ruling in the Minnesota Rate Cases (I9I3) 230 U. S. 352, 455, 33 Sup. Ct. 729,762 , is as follows:
} 
uation Act, shows the "present value" of lands, both those devoted to carrier purposes and those held for purposes other than those of a common carrier. "Present value," as that term is here used, was defined by the late Director Prouty as follows :

"Present value . . . . is arrived at by ascertaining the number of acres of land owned or used by the carrier ... : and multiplying this acreage by a market value determined from the present market value of similar adjacent and adjoining lands. Due allowance is made for any peculiar value which may attach by reason of the peculiar adaptability of the land to railroad use."

The land section, in addition, reports separately the present value of lands which were donated to the carrier. Following the decision of the Supreme Court in the Kansas City Southern Railway mandamus proceedings, ${ }^{14 a}$ the land section reported the estimated cost of reacquiring railroad lands as of the present, until that portion of the Act which provided for such figures was repealed by Congress in June, I922. ${ }^{14 b}$ The accounting section deals with the records of carriers, their predecessors, construction companies, or others which throw light on the history of the railroads. It shows, where such information is obtainable, the original cost to the present owner and to its predecessor corporations. It sets forth the financial history of the carrier and predecessors, corporate history, the development of fixed physical property, history of corporate financing, capital stock and long-term debt, gross and net earnings, general balance sheet, investment in road and equipment, original cost to date, with separate statements as to the costs of lands, investments in other companies, aids, gifts, grants of right of way and donations received, materials and supplies on hand, etc.

Throughout the work of all sections the conditions of ownership and use are carefully observed; that is, property both owned and used is separately shown from that owned but not used, used but not owned, or jointly used or owned. All items susceptible of such division are shown separately by states.

It will thus be seen that the Bureau of Valuation reports to the Commission substantially every figure pertinent to the valuation of the railroads under any conceivable theory. Certainly it presents every item

"Assuming that the company is entitled to a reasonable share in the general prosperity of the communities which it serves, and thus to attribute to its property an increase in value, still the increase so allowed, apart from any improvements it may make, can not properly extend beyond the fair average of the normal narket value of land in the vicinity having a similar character. Otherwise we enter the realm of mere conjecture. We therefore hold that it was error to base the estimates of value of the right-of-way, yards, and terminals upon the so-called 'railway value' of the property. The company would certainly have no ground of complaint if it were allowed a value for these lands equal to the fair average market value of similar land in the vicinity, without additions by the use of multipliers, or otherwise, to cover hypothetical outlays. The allowances made below for a conjectural cost of acquisition and consequential damages must be disapproved." (Italics ours.)

${ }_{1 \mathrm{a}}$ Kansas City So. Ry. v. I. C. C. (1920) 252 U. S. I78, 40 Sup. Ct. I87.

${ }^{16}$ Public Act-No. 233-67th Congress, approved June 7, 1922. 
required by the Act, or which has ever been suggested in judicial review of the subject. It shows the cost of reproducing the property, an item important as representing an approximate measure of the amount any theoretical competitor would have to expend in developing a similar plant; it shows reproduction less depreciation, which may be considered as the present value of the physical units; the original cost to date, where obtainable, representing the investment actually made in the enterprise; the sacrifice in developing and attracting business; the adjusted or corrected balance sheet, showing the financial status of the carrier; and the corporate and financial history of the company, which explains, modifies, and throws light upon the other factors. Every record which could possibly assist in fixing or interpreting any of the above matters is examined and correlated.

It should be clearly understood that the Bureau of Valuation is an organization for the sole purposes of investigating and reporting facts to the Commission proper. It is not the function of the Bureau to draw ultimate conclusions or to make findings therefrom. These are within the province of the Commission itself, governed by judicial rules, in the light of its experience and with all the facts before it.

In view of the fact, as stated heretofore, that the valuation work has been prosecuted from the standpoint of obtaining all possible data bearing on the present and historical status of the railways, without confining its inquiry to the scope of any particular economic theory, it is available for the widest range of uses-by carriers themselves, by governmental bodies, and by the public. Some of its uses and the purposes to which it may be put may be briefly enumerated.

Broadly speaking, these uses may be treated under two heads: (I) those which are written into the Transportation Act of 1920 ; and (2) other and more general purposes for which the data is available but which have not been made obligatory under direct provision of law.

USES UNDER THE TRANSPORTATION ACT OF I92015 .

By Section $\mathrm{I} 5^{-\mathrm{a}}$ of the Act the Interstate Commerce Commission is required to prescribe just and reasonable rates under which the carriers as a whole, or as a whole in each rate group or territory, as the Commission may designate, may earn an aggregate net railway operating income equal to a fair return upon the aggregate value of the railway property used within that rate group in the service of transportation. It is also provided in Section ${ }^{5} 5^{-a}$ that whenever the value of the railway property held for and used in the service of transportation has been finally ascertained pursuant to Section I9-a such value shall be deemed to be the value as the term is there used. In other words, the findings of the Commission as a result of the valuation work shall be used for the purposes of Section $x^{5-a}$. It is not to be assumed that the sum of

is Act of Feb. 28, I920 (4I Stat. at L. 456). 
the values of physical elements, the original cost of the plant, or any other single factor or combination of factors, will be the sole and only measure of the value to be ascertained, but the courts repeatedly have pointed out that such physical elements, modified by other factors, must be considered in arriving at "fair value."

${ }^{10}$ The following quoted excerpt from the opinion of the court in the case of Smyth v. Ames (I898) I69 U. S. 466, 546, I8 Sup. Ct. 4I8, 434, is the clearest and most concise statement of the factors which must be given consideration in a determination of the "fair value" upon which the carrier is entitled to earn a return which has so far been announced by the courts in any one case:

"We hold, however, that the basis of all calculations as to the reasonableness of rates to be charged by a corporation maintaining a highway under legislative sanction must be the fair value of the property being used by it for the convenience of the public. And, in order to ascertain that value, the original cost of construction, the amount expended in permanent improvements, the amount and market value of its bonds and stock, the present as compared with the original cost of construction, the probable earning capacity of the property under particular rates prescribed by statute, and the sum required to meet operating expenses, are all matters for consideration, and are to be given such weight as may be just and right in each case."

There is an additional value which inures to a public utility by reason of its being an assembled and established plant doing business and earning money, which is defined as "going concern value" to distinguish it from physical or structural value, and this additional value has been held by the Supreme Court to be a property right which must be considered in determining the value of the property upon which the utility has a right to make a fair return. This in effect was the language of the Court in Des Moines Gas Co. v. Des Moines (19I5) 238 U. S. I53, I65, 35 Sup. Ct. 8II, 8I5, and the same principle has been stated by the Court in Omaha v. Onaha Water Co., supra note 4; Cedar Rapids Gaslight Co. v. Cedar Rapids, supra note 4; Denver v. Denver Union Water Co. (I9I8) 246 U. S. I78, I92, 38 Sup. Ct. 278, 283; Knoxville v. Knoxville Water Co., supra note 4 ; National Waterworks Co. v. Kansas City (1894, C. C. A. 8th) 62 Fed. 853.

The ordinary conception of the value of a private enterprise independent of government regulation is derived from a consideration of its earnings, past, present and future, and the decisions of the courts are in accord with this economic law. In Monongahela Navigation Co. v. U. S. (1893) I48 U. S. 312, I3 Sup. Ct. 622,627 , the Supreme Court said: "The value of property, generally speaking, is determined by its productiveness-the profits which its use brings to the owner." This same theory was stated by the Court in Cleveland Railway Co. v. Backins (1894) I54 U. S. 439, 445, I4 Sup. Ct. I122, Ir24; Cotting v. Kansas City Stockyards, supra note 4; Adams Express Co. v. Ohio State Auditor (1897) I66 U. S. 185, 17 Sup. Ct. 604 .

The element of value defined as "good will" has been consistently eliminated from consideration in the case of public utilities which are in the possession of a monopoly, but it may be that the business of a railroad, being highly competitive in character, would justify the inclusion of an item of good will in its valuation. The following cases illustrate the attitude of the Supreme Court with reference to the consideration of "good will" which inures to a public utility as an incident to the possession of a monopoly: Cedar Rapids Gaslight Co. v. Cedar Rapids, supra note 4; Willcox v. Consolidated Gas Co., supra note 4; Omaha v. Omaha Water Co., supra note 4.

"Franchise value" has been recognized in the following cases: Willcox $v$. Consolidated Gas Co., supra note 4; Monongahela Navigation Co. v. United States, sutpra note I6; Cotting v. Kansas City Stock Yards (1897, C. C. D. Kan.) 82 Fed. 
The Transportation Act requires the Commission to designate the limits of rate groups and to determine the aggregate value of railway properties within such groups. Having determined that value as a whole, it shall prescribe rates which will yield as nearly as may be a reasonable return on the value of the properties. If the rate structure is too low, there will immediately arise, as in the past, the question of confiscation. Therefore, it follows that the value must be established definitely on legal grounds. With the value of each rate group determined, it becomes possible to test the rate level as between the different groups and to modify or adjust such rate levels in accordance with the needs of the country as a whole. The valuation reports ${ }^{17}$ show the property devoted to common carrier service separately for each state and for the railroad system as a whole, so that it becomes possible to apportion the properties used in interstate, as distinguished from intrastate, service, and to fix rates for these two classes of traffic.

Under the same Section, I5-a, the Commission is required to determine the value of each individual railroad property and to ascertain the net railway operating income under the rates prescribed in the preceding paragraph. If this return is in excess of the figure set by the Commission as reasonable, one-half of such excess is impounded by the carrier in a reserve fund, the uses of which are enumerated in the Act; the remaining one-half is to be recaptured by the Commission and added to the contingent fund from which loans shall be made to railroads in accordance with the provisions of the Act. It is therefore evident that the valuation work conducted under Section I9-a is essential to the fulfillment of this provision.

Under Section 5, paragraph 4, the Commission is required to prepare and adopt a plan for the consolidation of the railways in the United States into a limited number of systems, the par. value of the bonds, together with the capital stock outstanding, of which shall not exceed the value of the consolidated properties as determined by the Commission under Section I9-a of the Valuation Act. In this paragraph it is expressly provided that the Commission shall proceed immediately to the ascertainment of such value of the properties involved in any

850; Matter of Brooklyn (I893) 73 Hun, 499, (1894) I43 N. Y. 596, (I897) I66 U. S. 685, I7 Sup. Ct. 718; Spring Valley Water Works Co. v. City \& County of San Francisco (1903, C. C. N. D. Calif.) 124 Fed. 574, and (1908, C. C. N. D. Calif.) $\mathrm{x} 65$ Fed. 667; Louisville \& Nashville Ry. v. Railroad Commission of Alabana (I912, N. D. Ala.) I96 Fed. 800; National Waterworks Co. v. Kansas City (1894, C. C. A. 8th.) 62 Fed. 853, 865.

This is not a complete list of the decisions of the courts upon the many questions involved in arriving at the "fair value" upon which a utility should be allowed to earn a return. The citations given, however, comprise a fairly representative number of the adjudicated cases on this important subject.

${ }^{17}$ The tentative valuation of a carrier's property as served by the Interstate Commerce Commission in compliance with the provisions of Section I9-a of the Act to Regulate Commerce. 
proposed consolidation. The valuation so fixed should also form the basis for the rental of property by one carrier to another, and the basis of payment for joint use of facilities.

Exclusive of the consolidations above referred to, the total value of securities issued by a corporation should not exceed the value of the properties as determined by the Commission, and no carrier may put out a security issue without the approval of the Commission having been first obtained; thus security issues, both existing and proposed, rest directly upon the value as determined by Section r9-a.

Carriers are authorized to set up, with the approval of the Commission, reserve and depreciation funds, and the additions which may be made in any year are based upon percentages of the value as determined under the Valuation Act. Both the amount and the uses to which the reserve and depreciation funds may be devoted are set forth in detail in the Transportation Act.

The Commission is empowered by the Act to make loans to carriers out of the revolving fund above described, and to lease to carriers equipment purchased out of that fund. It is implied in the Transportation Act that the adequacy of the security for such loans shall be tested by the value of the properties, together with other obvious considerations relating to the carrier applying for the loan.

\section{GENERAL PURPOSES FOR WHICH AVAILABLE BUT NOT WRITTEN INTO $\mathrm{LAW}^{18}$}

In recounting the circumstances and reasons which led to the adoption of the Valuation Act, reference has been made to the utility of an appraisal in testing the accuracy of the railway balance sheet as reflecting the financial status of the corporation. The necessity for this from the standpoint of the regulating body is apparent, but scarcely less important in the effect on the investing public. For many years railroad credit has been impaired to such an extent that it has been impossible for carriers to finance their operations on an adequate scale or at reasonable interest charges. Everything which will tend to restore proper confidence is greatly to be desired. A complete inventory and exposition of assets, financial condition, and operating revenues and

${ }^{18}$ See Artaud, Uses of Vahuation and Purposes to Which it may be Put, contained in hearings on Independent Offices Appropriation Bill for 1923 before sub-committee of House Committee on Appropriations, Dec. 2I, I92r, pp. 339-358.

The essential uses of a valuation of railroad properties were stated by the Commission in its recommendations to Congress to be as follows:

"(a) To obtain a trustworthy estimate of the relation existing between the present worth of railroad property and its cost to its proprietors;

(b) In determining whether rates as fixed by the government are confiscatory;

(c) In connection with railway taxation;

(d) In the ascertainment of a proper depreciation reserve;

(e) In testing the accuracy of the balance sheet of the carriers;

(f) To the organization of railway statistics in general;

(g) In determining whether the railroads are under or over capitalized." 
expenses, together with assurance that the balance sheets correctly represent the financial standing of the corporations, are best calculated to produce this result. The impression is broadcast that many railway securities are heavily "watered" and whether or not this statement is well founded, it is necessary to determine that fact. This can only be done by an appraisal of the physical properties.

Under the Clayton Act,19 purchases of supplies for construction or maintenance of any kind amounting. to $\$ 50,000$ in any year can be made with individuals or firms having interlocking officers or directors with the carrier, only through competitive bidding under rules prescribed by the Commission. When such a contract is made, the carrier shall file within thirty days a detailed statement of the transaction with the Commission. The Bureau of Valuation has collected information relative to every conceivable form of construction or purchase, and this data should be of real value in checking the reasonableness of prices and the character of work done under such contracts. It should form the basis for estimates, or at least a criterion for checking every new contract or estimate.

No discussion of the possibilities of government acquisition, either outright or in any modified form, can be intelligently carried forward, nor can any proposed plan be considered, without full knowledge of the value of the properties affected.

The work of the Bureau of Valuation should, and doubtless will, be largely used in connection with the taxation of railroad properties. Closely connected with the question of reasonable railway rates stands the question of reasonable railway taxation, and the outstanding fact is that the value of corporate property, real and personal, is made the basis of public levy. Only a few states tax railways on the basis of earnings, and there is no tendency for this practice to become general. As the valuation of each carrier is determined by the Commission, this figure is served upon the states within which the carrier is located, together with the underlying data showing the apportionment of the property among the several states. ${ }^{20}$ There is thus made available for each state not only the appraisal of the property within its limits, but also of the system as a whole. Each state, therefore, has at its hand full information upon which it may proceed to tax the portion within its

${ }^{19}$ Sec. Io of Act of October 15, I9r4 (38 Stat. at I. 730).

${ }^{20}$ Act of March I, I913 (37 Stat. at L. 70I).

(h) "Whenever the Commission shall have completed the tentative valuation of the property of any common carrier, as herein directed, and before such valuation shall become final, the Commission shall give notice by registered letter to the said carrier, the Attorney-General of the United States, the governor of any State in which the property so valued is located, and to such additional parties as the Commission may prescribe, stating the valuation placed upon the several classes of property of said carrier, and shall allow thirty days in which to file a protest of the same with the Commission. If no protest is filed within thirty days, said valuation shall become final as of the date thereof." 
borders. Whether it makes use of this information or not lies within its own decision, but it is a matter of the highest concern to the country as a whole that the methods adopted within the several states be uniform and just.

One of the major features in the underlying report of the Bureau of Valuation's Accounting Section, published by the Commission, is a financial and corporate history of the carrier. This contains a full and accurate statement of facts without inference being drawn therefrom. Its utility is apparent. If much or any of the unsound financing against which so much popular criticism has been directed has been practiced, that fact will appear; if not, the record will show for itself. If the former, an exposition of the pertinent facts will do much toward correcting the situation, both by throwing the light of publicity on the subject and by pointing the way toward corrective and preventive legislation. If the latter, a clearing away of suspicion will greatly benefit the railroads themselves, the investing public and the credit structure of the entire country.

The appraisal of all the railroads within the United States is, without question, the most monumental undertaking of its kind in the history of the world. Inventories and appraisals have been made from the time of Caesar Augustus, through William the Conqueror's Domesday Books to the present. France, Germany, and Switzerland have each engaged in work of the sort, but none have ever approached this in magnitude or scope. During its progress, literally thousands of engineers, accountants, lawyers, and operating officials have been concerned with and have studied the problems presented, some from the standpoint of safeguarding the private property interests, others from the angle of regulating and conserving the welfare of the public. The result is that questions of public policy relating to the railroads and other utilities are receiving more real and constructive thought by a numerous, well trained, and competent body of men than ever before. The effect on public good is indirect, but nevertheless sure and potent.

A consideration, also indirect, but above all else in importance, is the effect which such an inquiry must have on future legislation. It is universally true that action on vital and abstruse problems is delayed until the need can no longer be denied or postponed. When a crisis is reached, steps are taken in the phase which is most pressing and apparent at the time. Piecemeal legislation results. More often than not the effects of the remedial measures upon the larger but less immediate aspects of the situation are not adequately considered, or else insufficient information is available to permit sound and well reasoned decision. Laws have been passed, supplemented, or amended, as occasion demanded, until the legal structure has become a patchwork, rather than a homogeneous and consistent unity. A law, no matter how ill-advised, once on the statute books carries with it the weight of precedent and establishes rights and obligations which cannot lightly be cancelled or 
swept aside. It in a measure controls and directs subsequent legislation. It is axiomatic that all laws should be made in light of the fullest possible data, both present and historical, concerning the subject in hand, so that they may be measured in terms of ultimate as well as immediate effects. The Valuation Act was designed to provide information for certain specific uses, but it was wisely framed as a complete and exhaustive inquiry; no essential thing is omitted from its scope. It will serve the immediate purposes, but it will also provide the basis and background for future consideration of other features. Only time can tell the extent to which ensuing legislation may be controlled or influenced by its findings, but since these consist of nothing more or less than statements of absolute and unquestioned facts, it is safe to say that the solution of public utility problems will be wise or unwise, beneficial or harmful, in direct proportion to the weight given the experience of the past and present conditions as set forth in the valuation reports. The deductions drawn from them and the remedies suggested may be open to argument, but the underlying facts are immutable and not subject to discussion. 